\title{
Kajian Kritis Konsep Pembajakan di Bidang Hak Cipta Dalam Perspektif Hukum Positif dan Hukum Islam
}

\author{
Riandhani Septian Chandrika, Raymond Edo Dewanta \\ Magister Kenotariatan, Fakultas Hukum, Universitas Airlangga \\ dhaniunited@gmail.com / raymond.edo.dewanta@gmail.com
}

\begin{abstract}
The existence of Law No. 28 of 2014 on Copyright provides protection and appreciation for every creator of his creations. It aims to support and encourage the emergence of creative ideas for the advancement of Science and art. However, the reality is still encountered piracy done by the irresponsible person. In this study, we want to critically examine the concept of piracy in the copyright field from the perspective of positive law and Islamic law to find solutions to overcome the problem of piracy that is happening in the community. This article will analyze with a legal research method that will analyze in a descriptive. This article generates a conclusion that in Islam, the term is not known piracy. However, when it is reviewed from the essence of piracy, it is the theft of other proprietary rights that should be maintained and respected in order not to cause harm to the copyright owner. The prohibition of piracy is based on Q.S. Al - Baqarah verses 188 and Q.S. Al - Maidah verses 38. Copyright piracy is an unauthorized or illegal reproduction and is subsequently distributed against a product or item registered as copyright. Law enforcement against violations in the copyright field by law enforcement officers can be done by preventive and repressive.
\end{abstract}

Keywords : piracy, copyright, postive law, Islamic law.

\begin{abstract}
Abstrak
Keberadaan Undang - Undang Nomor 28 Tahun 2014 tentang Hak Cipta memberikan perlindungan dan penghargaan bagi setiap pencipta atas hasil ciptaanya. Hal tersebut bertujuan untuk menunjang dan mendorong munculnya ide - ide kreatif guna kemajuan ilmu pengetahuan dan seni. Namun, realitanya masih banyak ditemui pembajakan yang dilakukan oleh oknum - oknum yang tidak bertanggung jawab. Dalam penelitian ini hendak mengkaji secara kritis konsep pembajakan dalam bidang hak cipta dari perspektif hukum positif dan hukum islam guna mencari solusi ayng tepat untuk mengatasi permasalahan pembajakan yang marak terjadi di masyarakat. Artikel ini akan menganalisa dengan metode penelitian hukum yang akan menganalisa secara deskriptif. Analisanya menghasilkan suatu koklusi bahwa dalam Islam, tidak dikenal istilah pembajakan. Akan tetapi, apabila ditinjau dari hakekatnya pembajakan merupakan pencurian hak milik orang lain yang seharusnya dijaga dan dihormati agar tidak menimbulkan kerugian bagi pemilik hak cipta tersebut. Larangan melakukan pembajakan didasarkan pada Q.S. Al - Baqarah Ayat 188 dan Q.S. Al - Maidah ayat 38. Pembajakan hak cipta merupakan penggandaan secara tidak sah atau ilegal dan selanjutnya di distribusikan terhadap suatu produk atau barang yang terdaftar sebagai hak cipta. Penegakan hukum terhadap pelanggaran di bidang hak cipta oleh aparat penegak hukum dapat dilakukan dengan cara preventif dan represif.
\end{abstract}

Kata Kunci: pembajakan, hak cipta, hukum positif, hukum islam. 


\section{Pendahuluan}

Indonesia sebagai Negara Kepulauan memiliki keanekaragaman seni budayanya yang sangat kaya. Hal ini sejalan keanekaragaman etnik, suku bangsa dan agama yang secara keseluruhan merupakan potensi nasional yang perlu di lindungi. Kekayaan seni dan budayanya itu merupakan salah satu sumber dari karya intelektual yang dapat dan perlu dilindungi oleh undang- undang. Secara garis besar HKI dibagi menjadi 2 (dua) bagian, yaitu hak cipta (copyright) termasuk di dalamnya hak terkait, dan yang kedua adalah hak atas kekayaan industri (Industrial property rights). Hak kekayaan industri terbagi atas paten (patent), merek (trademark), desain industri (industrial design), rahasia dagang (trade secret), desain tata letak sirkuit terpadu (layout design of integrated circuit), penanggulangan praktek persaingan curang (repression of unfair competition).

Hak cipta merupakan hak eksklusif bagi penciptanya atau penerima hak untuk mengumumkan atau memperbanyak ciptaannya atau memberikan izin untuk itu. Oleh sebab itu, hak tersebut hanya sematamata diperuntukkan bagi pemegangnya sehingga tidak ada pihak lain yang boleh memanfaatkan hak tersebut tanpa izin pemegangnya. Di Indonesia, dengan lahirnya Undang - Undang Nomor 28 Tahun 2014 tentang Hak Cipta, yang selanjutnya disebut UU Hak Cipta, merupakan landasan hukum dalam memberikan perlindungan terhadap hak cipta. Adapun yang dilindungi oleh UU Hak Cipta adalah hak atas benda atau hasil karya cipta pencipta, bukan benda yang merupakan perwujudan dari hak tersebut. Perlindungan terhadap hak cipta bertujuan untuk memberikan kepastian hukum dan kepastian hak kepada pencipta atau pemegang hak agar tidak ada pihak lain yang merampas, membajak hak tersebut tanpa seizin dari pencipta atau pemegang hak.

Dalam Pasal 40 ayat (1) UU Hak Cipta disebutkan bahwa ciptaan yang dilindungi meliputi ciptaan dalam bidang ilmu pengetahuan, seni dan sastra, yang terdiri atas :

a) buku, pamflet, perwajahan karya tulis yang diterbitkan, dan semua hasil karya tulis lainnya;

b) ceramah, kuliah, pidato, dan Ciptaan sejenis lainnya;

c) alat peraga yang dibuat untuk kepentingan pendidikan dan ilmu pengetahuan;

d) lagu dan/atau musik dengan atau tanpa teks;

e) drama, drama musikal, tari, koreografi, pewayangan, dan pantomim;

f) karya seni rupa dalam segala bentuk seperti lukisan, gambar, ukiran, 
kaligrafi, seni pahat, patung, atau kolase;

g) karya seni terapan;

h) karya arsitektur;

i) peta;

j) karya seni batik atau seni motif lain;

k) karya fotografi;

1) Potret;

m) Karya sinematografi;

n) terjemahan, tafsir, saduran, bunga rampai, basis data, adaptasi, aransemen, modifikasi dan karya lain dari hasil transformasi;

o) terjemahan, adaptasi, aransemen, transformasi, atau modifikasi ekspresi budaya tradisional;

p) kompilasi Ciptaan atau data, baik dalam format yang dapat dibaca dengan Program Komputer maupun media lainnya;

q) kompilasi ekspresi budaya tradisional selama kompilasi tersebut merupakan karya yang asli;

r) permainan video; dan

s) Program Komputer.

Selain perlindungan terhadap hak cipta, UU Hak Cipta juga memberikan perlindungan terhadap hak terkait. Maksud dari hak terkait adalah hak yang berkaitan dengan hak cipta yang merupakan hak eksklusif bagi :

a) hak moral Pelaku Pertunjukan;

b) hak ekonomi Pelaku Pertunjukan; c) hak ekonomi Produser Fonogram; dan

d) hak ekonomi Lembaga Penyiaran.

Oleh sebab itu penggunaan terhadap karya cipta atau hak terkait tanpa izin dari penciptanya atau pemegang hak, maka akan dikenakan sanksi pidana seperti yang tercantum dalam Pasal 112 - 119 UU tentang Hak Cipta. Penggunaan karya cipta tanpa izin dari pencipta sering dikenal dengan pembajakan karya cipta. Pembajakan terhadap karya orang lain seperti buku dan rekaman adalah salah satu bentuk dari tindak pidana hak cipta yang dilarang dalam UU Hak Cipta. Dilihat dari pasal demi pasal di dalam UU Hak Cipta jauh lebih sempurna karena adanya hukuman pidana berupa denda yang merupakan pasal yang diharapkan dapat menjadikan para pembajak tersebut jera. Namun, pada kenyataannya pembajakan masih berlangsung. Perkembangan pembajakan saat ini terjadi karena penegakan hukum yang dilakukan oleh aparat penegak hukum dalam hal ini pihak kepolisian tidaklah dijalankan secara menyeluruh dan tuntas, atau dengan kata lain dijalankan dengan setengah hati sehingga tidak ada satu kasus pembajakan di bidang perfilman yang dapat dipakai sebagai yurisprudensi (Wiryanto, 2004 : 318).

Penanggulangan tindak pidana hak cipta pada bidang pembajakan, seperti 
pembajakan CD dan VCD tidak bisa hanya kesadaran masyarakat agar pembajakan tidak marak terjadi. Dalam hal ini hukum pidana dalam bekerjanya memiliki kelemahan / keterbatasan, kelemahan atau keterbatasan kemampuan hukum pidana dalam penanggulangan kejahatan telah banyak diungkapkan oleh para sarjana. Menurut Muladi, "penegakan Hukum pidana dalam kerangka sistem peradilan tidak dapat diharapkan sebagai satusatunya sarana penanggulangan kejahatan yang efektif, mengingat kemungkinan besar adanya pelaku-pelaku tindak pidana yang berada di luar kerangka proses peradilan pidana" (Muladi, 1995 : vii). Senada dengan Muladi, Donald R Taft dan Ralph W England, seperti dikutip Barda Nawawi Arief, menyatakan bahwa "efektifitas hukum pidana tidak dapat diukur secara akurat, Hukum hanya merupakan salah satu sarana kontrol sosial, kebiasaan keyakinan agama, dukungan dan pencelaan kelompok, penekanan dari kelompok-kelompok interest dan pengaruh dari pendapat umumnya merupakan sarana yang lebih efisien dalam mengatur tingkah laku manusia dari pada sanksi hukum" (Arief, $1998: 42$ ).

Penegakan hukum atas hak cipta biasanya dilakukan oleh pemegang hak cipta dalam hukum perdata. Namun, ada pula sisi hukum pidana yang sanksi pidananya secara dikenakan kepada aktivitas pemalsuan yang serius. Saat ini semakin lazim pada perkara-perkara lain. Sanksi pidana atas pelanggaran Hak Cipta di Indonesia secara umum diancam dengan hukuman penjara paling singkat 1 (satu) bulan dan paling lama 7 (tujuh) tahun yang dapat disertai maupun tidak disertai denda sejumlah paling sedikit Rp 100.000.000,00 (seratus juta rupiah) dan paling banyak $\mathrm{Rp}$ 5.000.000.000,00 (lima milyar rupiah), sementara ciptaan atau barang yang merupakan hasil tindak pidana hak cipta serta alat-alat yang digunakan untuk melakukan tindak pidana tersebut dirampas oleh Negara untuk dimusnahkan.

Kalau dilihat dan diamati dari tahun 1980-an sampai sekarang bisa ditarik suatu garis besarnya. Pertama adalah masalah law enforcement, penegakan dan penanganan pelanggaran terhadap Undang-Undang No. 8 tahun 1982 yaitu bahwa film tidak disensor saja tidak bisa ditangani. Itu membuktikan adanya komponen dalam penegakan Hukum yang tidak berlajan dari kurun tahun 1980-an sampai sekarang. Jadi sudah sekitar 20 tahunan lebih masalah ini masih menjadi permasalahan saja sama seperti "Never Ending Story". Dalam hal ini diragukan juga keseriusan pihak aparat penegak hukum dalam menangani pembajakan Hak Cipta (Wiyanto, 2004 : 318).

Dengan adanya korelasi antara pelanggaran hak cipta dengan ancaman 
pidana diharapkan mampu untuk mendorong upaya penanggulangan tindak pidana dibidang HAKI khususnya Hak Cipta yang sedang marak-maraknya terjadi di Indonesia. Berkaitan dengan hal tersebut di dalam Pasal 113 ayat (4) UU Hak Cipta menegaskan :

(3) Setiap Orang yang dengan tanpa hak dan/atau tanpa izin Pencipta atau pemegang Hak Cipta melakukan pelanggaran hak ekonomi Pencipta sebagaimana dimaksud dalam Pasal 9 ayat (1) huruf a, huruf $b$, huruf e, dan/atau huruf g untuk Penggunaan Secara Komersial dipidana dengan pidana penjara paling lama 4 (empat) tahun dan/atau pidana denda paling banyak Rp1.000.000.000,00 (satu miliar rupiah)

(4) Setiap Orang yang memenuhi unsur sebagaimana dimaksud pada ayat (3) yang dilakukan dalam bentuk pembajakan, dipidana dengan pidana penjara paling lama 10 (sepuluh) tahun dan/atau pidana denda paling banyak Rp4.000.000.000,00 (empat miliar rupiah).

Dari ketentuan tersebut, maka dengan pembuktian yang cukup sederhana sebenarnya aparat penegak hukum sudah dapat melakukan tindakan terhadap praktek pembajakan, sehingga kerugian Negara yang diakibatkan oleh praktek pembajakan tersebut dapat dikurangi. Apabila hal tersebut juga dimaksudkan sebagai upaya untuk memberantas tindak pidana pembajakan nampaknya hal tersebut tidak akan berjalan efektif, praktek pembajakan yang merupakan pelanggaran terhadap UU Hak Cipta, sudah sepatutnya jika sanksi pidana yang dikenakannya di dasarkan pula pada UU Hak Cipta. Pelanggaran hak kekayaan intelektual khususnya Hak Cipta terjadi di Indonesia, setelah bangsa Indonesia diprotes oleh banyak Negara terutama Amerika Serikat atas pembajakan yang terjadi baik pada bidang Hak Cipta, Merek maupun Paten.

Negara-negara yang merasa dirugikan menempatkan Indonesia sebagai Priority Watch List sebagaimana juga yang diberlakukan pada Negara-negara Cina, Argentina dan Rusia. Desakan-desakan dari Negara maju inilah yang telah menggugah pemerintah Indonesia untuk mulai berusaha terus menegakkan hukum dalam bidang HKI, sehingga peringkatnya sudah agak turun tapi masih tetap menjadi incaran Negara-negara besar karena Indonesia dianggap gudangnya pembajakan. Setelah diberlakukannya UU Hak Cipta, para pencipta pada bidang seni sastra dan ilmu pengetahuan mendapat perlindungan hukum sehingga tidak lagi mematikan kreatifitas para penciptanya. 
Untuk menilai orginalitas dari artikel ini, maka terlabih dahulu akan dilakukan literatur review dengan tujuan untuk dapat memahami permasalaha secara benar dan gambaran yang berkenaan dengan apa yang sudah di kerjakan orang lain sebelumnya. Mujahid Quraisy dalam artikelnya Hak Kekayaan Intelektual (HaKI) dalam perspektif hukum Islam. Mujahid Quraisy menjabarkan bahwa kekayaan intelektual memiliki dua dimensi yaitu dimensi publik dan privat. Kekayaan intelektual dapat menjadi barang publik jika dijadikan sebagai sarana atau alat untuk mencapai tujuan-tujuan produksi, distribusi dan konsumsi masyarakat dalam mengembangkan kualitas dirinya dengan tanpa menghilangkan identitas penemunya (Quraisy, 2011 : 40) Kekayaan intelektual sebagai milik pribadi menjadi syubhat apabila digunakan oleh orang lain untuk mencari keuntungan. (Hanintjo, 1988 : 55).

\section{Metode Penelitian}

Untuk menjawab permasalahan dalam artikel ini, maka akan digunakan metode penelitian hukum berkarakter yuridis normatif. Penelitian ini akan mengkaji norma hukum yang dalam bentuk hukum positif. Selanjutnya akan dianalisa secara deskriptif analitis dimana dalam pembahasannya akan menggambarkan konsep hukum dengan tinjauaan peraturan perundang - undangan yang berlaku dan dikaitkan dengan teori hukum yang dikemukakan oleh para ahli.

Sehubungan karakter penelitian ini adalah penelitian hukum yuridis normatif, maka akan menggunakan sumber hukum primer yang meliputi peraturan perundang - undangan terkait dengan hak cipta serta al-qur'an dan hadist. Untuk sumber hukum sekunder akan diambil dari literatur buku dan artikel yang terkait dengan topik hak cipta atau kekayaan intelektual. Sumber bahan hukum tersebut diperoleh melalui studi kepustakaan. Langkah selanjutnya adalah analisa data dengan menjabarkan dan menafsirkan data berdasarkan asas asas, norma-norma, teori/doktrin ilmu hukum khususnya terkait dengan topik kekayaan intelektual.

\section{Pembahasan}

\section{1) Konsep Pembajakan Dalam Perspektif Islam Dan Hukum Positif}

Hakekatnya hak cipta merupakan hak yang diberikan kepada seseorang atas jerih payah dan daya upayanya untuk meluangka waktunya membuat suatu karya dalam bentuk ilmu pengetahuan, seni maupun sastra untuk menghindari penyalahgunaan atas karyanya guna mencari keuntungan sepihak. Hak cipta memberikan perlindungan dari pemiliknya dari kerugian yang dialami akibat 
penyalahgunaan dari orang lain untuk mencari keuntungannya pribadi.

Dalam Al Qur'an tidak tidak ada dalil yang meyebutkan mengenai pembajakan. Dalam Al Qur'an Q.S. Al - Baqarah Ayat 188 yang artinya : “....dan janganlah kamu makan harta diantara kamu dengan jalan yang batil, dan (janganlah) kamu menyuap dengan harta itu kepada para hakim, dengan maksud agar kamu dapat memakan sebagian harta orang lain itu dengan jalan dosa, padahal kamu mengetahui”.

Dalam Q.S Al Maidah ayat 38 yang artinya "Laki-laki yang mencuri dan perempuan yang mencuri, potonglah tangan keduanya (sebagai) pembalasan bagi apa yang mereka kerjakan dan sebagai siksaan dari Allah. Dan Allah maha perkasa lagi maha bijaksana". Dari kedua ayat tersebut Allah SWT melalui firmannya telah secara tegas mengharamkan bagi orang - orang yang beriman untuk memanfaatkan, memakan, dan menggunakan harta orang lain tanpa seizin pemiliknya. Dengan demikian, hak cipta tersebut memang diakui keberadaaanya untuk melindungi kepentingan pencipta karya.

Untuk menyikapi firman Allah SWT tersebut, Majelis Ulama Indonesia menetapkan fatwanya Nomor 1/MUNAS VII/MUI/15/2005 tentang Perlindungan Hak Kekayaan Intelektual (HAKI), yang di dalamnya meliputi Hak Perlindungan
Varietas Tanaman, Hak Rahasia Dagang, Hak Desain Industri, Hak Desain Tata Letak Terpadu, Paten, Hak Atas Merek dan Hak Cipta. Dalam Fatwa MUI tersebut mengatur bahwa suatu hak yang mendapatkan perlindungan hukum tidak bertentanga dengan hukum Islam, mengandung unsur akad baik akad mu'awadhah maupu akad tabarru'at, dapat diwariskan dan di waqafkan.

Hukum islam dalam kaitannya dengan hak, menetapkan langkah hukum sebagai berikut :

a) Memberikan yang hak kepada yang berhak. Misalnya zakat harus diberikan oleh mereka yang berkewajiban kepada yang berhak. Dan shalat wajib dilakukan oleh mereka yang berkewajiban, hanya ditujukan kepada Allah SWT dan sebagainya.

b) Melindungi hak. Syariat islam memberikan perlindungan hak dari segala bentuk penganiayaan, kecurangan, penyalalahgunaan, dan perampasan, sepuluh abad sebelum deklarasi Hak Asasi Manusia dikumandangkan.

c) Menggunakan hak dengan cara yang sah dan benar. Setiap manusia diberi wewenang menggunakan haknya sessuai dengan yang diperintahkan dan diizinkan oleh syariat, namun dalam menggunakan haknya tidak 
boleh melampaui batas dann tidak boleh menimbulkan kerugian pada pihak lain, baik yang sifatnya personal maupun publik.

d) Menjamin perpindahan hak dengan cara yang benar dan sah. Hukum islam melindungi perpindahan melalui prosedur dan cara yang benar, baik melalui transaksi, seperti jual beli atau perlimpahan, seperti dalam kasus jaminan hutang atau hak yang berkaitan dengan wewenang, atau berpindahnya hak perwalian dari orang tua kepada anak sepeninggal orang tua tersebut.

e) Menjamin hangus atau terhentinya hak dengan cara benar dan sah. Melalui prosedur dengan cara yang sah misalnya hangusnya hak suami istri melalui perceraian atau pengguguran hak secara suka rela, seperti tidak menggunakan hak menuntut ganti rugi.

Dalam Islam tidak mengenal istilah pembajakan tersebut. Akan tetapi, apabila ditinjau dari hakekat pembajakan yang mengambil keuntungan untuk kepentingan pribadi dari hasil karya orang lain tanpa seizinnya, maka tidak diperbolehkan dalam ketentuan hukum Islam Q.S. Al Baqarah ayat 188 yang mengharamkan sesama muslim untuk saling mengambil keuntungan dari muslim lainnnya dengan cara yang tidak baik.
Berdasarkan Pasal 1 angka 23 UU Hak Cipta yang dimaksud dengan pembajakan adalah penggandaan Ciptaan dan/atau produk Hak Terkait secara tidak sah dan pendistribusian barang hasil penggandaan dimaksud secara luas untuk memperoleh keuntungan ekonomi.

Secara etimologi, pembajakan dalam bahasa Inggris disebut piracy. Menurut Bryan A. Garner dalam Black's Law Dictionary, "piracy is the unauthorized and illegal reproduction or distribution of materials protected by copyright, patent, or trademark law" (Garner, 2004 : 1186). Jadi, piracy tersebut lebih kepada penggandaan secara tidak sah atau ilegal dan selanjutnya di distribusikan terhadap suatu produk atau barang yang terdaftar sebagai hak cipta, paten, atau merk. Hal yang sama diungkapkan oleh Aditya Pandu Wicaksono dan Deka Urumsah yang menyebutkan bahwa pembajakan adalah penggandaan atas hak cipta secara ilegal atau tanpa izin. (Wicaksono, 2017 : 24)

\section{2) Bentuk-Bentuk Pelanggaran Hak Cipta dan Ketentuan Sanksi Pidananya Dalam Hukum Positif}

Diadakannya undang-undang atau aturan hukum terhadap suatu masalah, biasanya disebabkan adanya hal-hal yang menimbulkan kerugian moral maupun material terhadap suatu pihak. Tujuan 
pengaturan berupa perlindungan bagi masyarakat atau sebuah komunitas dan sanksi terhadap kegiatan apa pun yang menyebabkan timbulnya kerugian itu, untuk memberikan terapi hukum serta pengajaran bagi para pelanggar aturan serta untuk meminimalisir kegiatankegiatan yang dapat merugikan orang lain tersebut.

Pelanggaran hak cipta atau karya buku sudah terjadi sejak berlakunya Auteurswet 1912 dan makin meningkat hingga berlakunya Undang-Undang Hak Cipta 1982. Auteurswet pada hakikatnya tidak mempunyai dampak terhadap perlindungan hak cipta. Mengingat masyarakat Indonesia pada waktu itu, yaitu masa berlakunya Auteurswet tersebut belum cukup mencapai tingkat pemahaman mengenai arti dan kegunaan hak cipta. Terdapat hambatan kultural atas perlindungan hak cipta pada masa itu. Perlindungan Hak Cipta secara individual pada hakikatnya merupakan hal yang tidak dikenal di Indonesia.

Suatu ciptaan oleh masyarakat dianggap secara tradisional sebagai milik bersama. Tumbuhnya kesadaran bahwa ciptaan itu perlu perlindungan hukum setelah dihadapinya bahwa ciptaan itu mempunyai nilai ekonomi. Adapun dalam pandangan tradisional segi nilai moral hak cipta lebih menonjol daripada nilai ekonomisnya. Baru setelah menonjol nilai ekonomi dari hak cipta, terjadilah pelanggaran terhadap Hak Cipta, seperti dalam bentuk tindak pidana pembajakan lagu atau musik, buku dan penerbitan, film dan rekaman video serta komputer. Pelanggaran terhadap Hak Cipta ini disebabkan oleh sikap dan keinginan sebagai (anggota) masyarakat kita untuk memperoleh keutungan dagang dengan cara mudah. Sebagai akibatnya bukan saja merugikan pencipta atau pemegang Hak Cipta, tetapi juga merugikan perekonomian pada umumnya.

Undang-Undang Hak Cipta 1997 telah menyediakan dua sarana hukum, yang dapat dipergunakan sekaligus untuk menindak pelaku pelanggaran terhadap hak cipta, yakni sarana hukum pidana dan hukum perdata. Pelanggaran terhadap hak cipta dapat dituntut secara pidana dan perdata sekaligus (Purwaningsih, 2005 : 158) Dalam Pasal 42 ayat (3) lama atau pasal 43B UUHC 1997 dinyatakan bahwa: Hak untuk mengajukan gugatan sebagaimana dimaksud dalam Pasal 42 tidak mengurangi hak negara untuk melakukan tuntutan pidana terhadap pelanggaran hak cipta.

Berdasarkan Pasal 42 ayat (3) lama atau Pasal 43B Undang-Undang Hak Cipta 1997, pelaku pelanggaran terhadap hak cipta, selain dituntut secara perdata, juga dapat dituntut secara pidana. Demikian Undang-Undang No 19 Tahun 2002 
tentang Hak Cipta juga telah menyediakan dua sarana hukum, yang dapat dipergunakan untuk menindak pelaku pelanggaran terhadap Hak Cipta, yaitu melalui sarana instrumen hukum pidana dan hukum perdata, bahkan, dalam Undang-Undang No 19 Tahun 2002 tentang Hak Cipta, penyelesaian sengketa di bidang hak cipta dapat dilakukan di luar pengadilan melalui arbitrase atau alternatif penyelesaian sengketa lainnya. Dalam Pasal 66 Undang - Undang No 19 Tahun 2002 tentang Hak Cipta dinyatakan bahwa: hak untuk mengajukan gugatan sebagaimana dimaksud dalam Pasal 55, Pasal 56, dan Pasal 65 tidak mengurangi hak Negara untuk melakukan tuntutan terhadap pelanggaran hak cipta. Ini berarti berdasarkan ketentuan Pasal 66 Undang-Undang No 19 Tahun 2002 tentang Hak Cipta, pelaku pelanggaran Hak Cipta, selain dapat dituntut secara perdata, juga dapat dituntut secara pidana.

\section{a) Bentuk-Bentuk Pelanggaran Hak Cipta}

Pengajuan tuntutan hak cipta dapat dilakukan secara pidana. UU Hak Cipta telah merumuskan perbuatan-perbuatan yang dikategorikan sebagai tindak pidana hak cipta. Tindak pidana hak cipta merupakan delik aduan (vide Pasal 120 UU Hak Cipta). Untuk dapatnya suatu perbuatan dilakukan penyidikan harus ada terlebih dahulu delik aduan dari pihak yang merasa haknya dirugikan. Selain itu, ancaman pidananya pun diperberat guna lebih melindungi pemegang hak cipta dan sekaligus memungkinkan dilakukan penahanan sebagaimana diatur dalam KUHAP.

Umumnya pelanggaran hak cipta didorong untuk mencari keuntungan finansial secara cepat dengan mengabaikan kepentingan para pencipta dan pemegang izin hak cipta. Perbuatan para pelaku jelas melanggar fatsun hukum yang menentukan agar setiap orang dapat mematuhi, menghormati, dan menghargai hak-hak orang lain dalam hubungan keperdataan termasuk penemuan baru sebagai ciptaan orang lain yang diakui sebagai hak milik oleh ketentuan hukum.

Faktor-faktor yang mempengaruhi warga masyarakat untuk melanggar HKI menurut Parlugutan Lubis antara lain adalah :

1) Pelanggaran HKI dilakukan untuk mengambil jalan pintas guna mendapatkan keuntungan yang sebesar-besarnya dari pelanggaran tersebut;

2) Para pelanggar menganggap bahwa sanksi hukum yang dijatuhkan oleh pengadilan selama ini terlalu ringan bahkan tidak ada tindakan preventif maupun represif yang dilakukan oleh para penegak hukum; 
3) Ada sebagian warga masyarakat sebagai pencipta yang bangga apabila hasil karyanya ditiru oleh orang lain, namun hal ini sudah mulai hilang berkat adanya peningkatan kesadaran hukum terhadap HKI;

4) Dengan melakukan pelanggaran, pajak atas produk hasil pelanggaran tersebut tidak perlu dibayar kepada pemerintah; dan

5) Masyarakat tidak memperhatikan apakah barang yang dibeli tersebut asli atau palsu (aspal), yang penting bagi mereka harganya murah dan tertjangkau dengan kemampuan ekonomi.

Dampak dari kegiatan tindak pidana hak cipta tersebut telah sedemikian besarnya merugikan terhadap tatanan kehidupan bangsa di bidang ekonomi, hukum dan sosial budaya. Di bidang sosial budaya, misalnya dampak semakin maraknya pelanggaran hak cipta akan menimbulkan sikap dan pandangan bahwa pembajakan sudah merupakan hal yang biasa dalam kehidupan masyarakat dan tidak lagi merupakan tindakan melanggar undang-undang (wet delicten). Pelanggaran hak cipta selama ini lebih banyak terjadi pada negara-negara berkembang (developing countries) karena ia dapat memberikan keuntungan ekonomi yang tidak kecil artinya bagi para pelanggar (pembajak) dengan memanfaatkan kelemahan sistem pengawasan dan pemantauan tindak pidana hak cipta. Harus diakui, upaya pencegahan dan penindakan terhadap pelanggaran hak cipta selama ini belum mampu membuat jera para pembajak untuk tidak mengulangi perbuatannya, karena upaya penanggulangannya tidak optimal.

Bentuk-bentuk pelanggaran hak cipta antara lain berupa pengambilan, pengutipan, perekaman, pertanyaan, dan pengumuman sebagian atau seluruh ciptaan orang lain dengan cara apapun tanpa izin pencipta/pemegang hak cipta, bertentangan dengan undang-undang atau melanggar perjanjian. Dilarang undangundang artinya UU Hak Cipta tidak memperkenankan perbuatan itu dilakukan oleh orang yang tidak berhak karena tiga hal yakni :

1) Merugikan pencipta,/pemegang hak cipta, misalnya memfotokopi sebagian atau seluruhnya ciptaan orang lain kemudian dijualbelikan kepada masyarakat luas ;

2) Merugikan kepentingan Negara, misalnya mengumumkan ciptaan yang bertentangan dengan kebijakan pemerintah di bidang pertahanan dan keamanan atau ;

3) Bertentangan dengan ketertiban umum dan kesusilaan, misalnya 
memperbanyak dan menjual video compact disc (VCD) porno.

Melanggar perjanjian artinya memenuhi kewajiban tidak sesuai dengan isi kesepakatan yang telah disetujui oleh kedua belah pihak, misalnya dalam perjanjian penerbitan karya cipta disetujui untuk dicetak sebanyak 2000 eksemplar, tetapi yang dicetak/diedarkan di pasar adalah 4000 eksemplar. Pembayaran royalty kepada pencipta didasarkan pada perjanjian penerbitan, yaitu 2000 eksemplar bukan 4000 eksemplar. Ini sangat merugikan bagi pencipta. Pelanggaran hak cipta menurut ketentuan Ikatan Penerbit Indonesia (IKAPI) pada tanggal 15 Februari 1984 dapat dibedakan dua jenis, yakni :

1) Mengutip sebagian ciptaan orang lain dan dimasukkan ke dalam ciptaan sendiri seolah-olah ciptaan sendiri atau mengakui ciptaan orang lain seolah-olah ciptaan sendiri. Perbuatan ini disebut palgiat atau penjiplakan yang dapat terjadi antara lain pada karya cipta berupa buku, lagu, dan notasi lagu, dan;

2) Mengambil ciptaan orang lain untuk diperbanyak dan diumumkan sebagaimana yang aslinya tanpa mengubah bentuk isi, pencipta, dan penerbit/perekam. Perbuatan ini disebut dengan piracy (pembajakan) yang banyak dilakukan pada ciptaan berupa buku, rekaman audio/video seperti kaset lagu dan gambar (VCD), karena menyangkut dengan masalah $a$ commercial scale.

Pembajakan terhadap karya orang lain seperti buku dan rekaman adalah salah satu bentuk dari tindak pidana hak cipta yang dilarang dalam Undang-Undang Hak Cipta. Pekerjaannya liar, tersembunyi, dan tidak diketahui orang banyak apalagi oleh petugas penegak hukum dan pajak. Pekerjaan tersembunyi ini dilakukan untuk menghindarkan diri dari penangkapan pihak kepolisian. Para pembajak tidak akan mungkin menunaikan kewajiban hukum untuk membayar pajak kepada negara sebagaimana layaknya warga negara yang baik. Pembajakan merupakan salah satu dampak negatif dari kemajuan iptek di bidang grafika dan elektronika yang dimanfaatkan secara melawan hukum (ilegal) oleh mereka yang ingin mencari keuntungan dengan jalan cepat dan mudah.

Ketentuan pidana untuk menjerat pelaku pembajakan diatur padal Pasal 113 UU Hak Cipta yang substansinya adalah sebagai berikut :

(1) Setiap orang yang dengan tanpa hak melakukan pelanggaran hak ekonomi sebagaimana dimaksud dalam pasal 9 ayat (1) huruf i untuk penggunaan secara komersial dipidana dengan 
pidana penjara paling lama 1 (satu) tahun dan/atau pidana denda paling banyak Rp100.000.000 (seratus juta rupiah).

(2) Setiap orang yang dengan tanpa hak dan/atau tanpa izin Pencipta atau pemegang Hak Cipta melakukan pelanggaran hak ekonomi Pencipta sebagaimana dimaksud dalam pasal 9 ayat (1) huruf $c$, huruf $d$, huruf $\mathrm{f}$, dan/atau huruf $h$ untuk penggunaan secara komersial dipidana dengan pidana penjara paling lama 3 (tiga) tahun dan/atau pidana denda paling banyak Rp500.000.000,00 (lima ratus juta rupiah).

(3) Setiap orang yang dengan tanpa hak dan/atau tanpa izin Pencipta atau pemegang Hak Cipta melakukan pelanggaran hak ekonomi Pencipta sebagaimana dimaksud dalam pasal 9 ayat (1) huruf a, huruf $b$, huruf e, dan/atau huruf g untuk penggunaan secara komersial dipidana dengan pidana penjara paling lama 4 (empat) tahun dan/atau pidana denda paling banyak Rp1.000.000.000,00 (satu miliar rupiah).

(4) Setiap orang yang memenuhi unsur sebagaimana dimaksud pada ayat (3) yang dilakukan dalam bentuk pembajakan, dipidana dengan pidana penjara paling lama 10 (sepuluh) tahun dan/atau pidana denda paling banyak Rp4.000.000.000,00 (empat miliar rupiah).

Dalam UU Hak Cipta, suatu perbuatan dapat disebut pembajakan apabila secara tanpa hak dan/atau tanpa izin pencipta atau pemegang hak cipta melakukan pelanggaran hak ekonomi pencipta berupa penerbitan ciptaan, penggandaan ciptaan dalam segala bentuknya, pendistribusian ciptaan atau salinannya, dan pengumuman ciptaan dengan maksud untuk penggunaan komersial.

\section{b) Unsur - Unsur Tindak Pidana Pembajakan}

Pasal 113 ayat (3) - (4) UU Hak Cipta menentukan unsur - unsur perbuatan pidana berupa pembajakan sebagai berikut

(3) Setiap orang yang dengan tanpa hak dan/atau tanpa izin Pencipta atau pemegang Hak Cipta melakukan pelanggaran hak ekonomi Pencipta sebagaimana dimaksud dalam pasal 9 ayat (1) huruf a, huruf $b$, huruf e, dan/atau huruf g untuk penggunaan secara komersial dipidana dengan pidana penjara paling lama 4 (empat) tahun dan/atau pidana denda paling banyak Rp1.000.000.000,00 (satu miliar rupiah).

(4) Setiap orang yang memenuhi unsur sebagaimana dimaksud pada ayat (3) 
yang dilakukan dalam bentuk pembajakan, dipidana dengan pidana penjara paling lama 10 (sepuluh) tahun dan/atau pidana denda paling banyak Rp4.000.000.000,00 (empat miliar rupiah).

Adapun unsur - unsur tindak pidana pembajakan adalah sebagai berikut :

\section{1) Setiap orang}

Pertama, unsur setiap orang. Ini menandakan yang menjadi subjek delik adalah siapapun. Kalau menurut KUH Pidana yang berlaku sekarang, hanya manusia yang menjadi subyek delik, sedangkan badan hukum tidak menjadi subyek delik. Tetapi dalam undang-undang khusus seperti Undang-Undang Tindak Pidana Ekonomi, badan hukum atau korporasi termasuk juga menjadi subyek delik. Dalam hal ini, barang siapa termasuk pula badan hukum atau korporasi (Hamzah, 1994 : 92) Dalam UU Hak Cipta, setiap orang bisa ditujukan kepada orang perseorangan atau badan hukum (vide Pasal 1 angka 27 UU Hak Cipta). Sebagai contoh pembajakan dalam nidang musik setiap orang antara lain dapat dtujukan kepada pelaku dan produser rekaman suara. Pelaku adalah aktor, pemusik, penari, atau mereka yang menampilkan, memperagakan, mempertunjukkan, menyanyikan, menyampaikan, mendeklamasikan, atau memainkan karya musik, drama, tari, sastra, folklor, atau karya seni lainnya. Produser rekaman suara adalah orang atau badan hukum yang pertama kali merekam dan memiliki tanggung jawab untuk melaksanakan perekaman suara atau bunyi, baik perekaman dari suatu pertunjukkan maupun perekaman suara atau perekaman bunyi lainnya.

\section{2) Tanpa hak dan/atau tanpa izin}

Unsur tanpa hak. Mengenai arti tanpa hak dari sifat melanggar hukum, dapat dikatakan, bahwa mungkin seseorang, tidak mempunyai hak untuk melakukan suatu perbuatan, yang sama sekali tidak dilarang oleh suatu peraturan hukum (Prodjodikoro, 1980 : 2) Menurut Pasal 1 angka 4 UU Hak Cipta, pemegang hak cipta adalah pencipta sebagai pemilik hak cipta, pihak yang menerima hak tersebut secara sah dari pencipta, atau pihak lain yang menerima lebih lanjut hak dari pihak yang menerima hak tersebut secara sah. Pemilik hak cipta dapat mengalihkan atau menguasakan sebagian atau seluruh haknya kepada orang/badan hukum baik melalui perjanjian, surat kuasa maupun dihibahkan atau diwariskan. Tanpa pengalihan tersebut, maka tindakan itu adalah merupakan tanpa hak.

\section{3) Pencipta atau pemegang hak cipta}


Berdasarkan Pasal 1 angka 2 UU Hak Cipta yang dimaksud dengan pencipta adalah seorang atau beberapa orang yang secara sendiri-sendiri atau bersama-sama menghasilkan suatu ciptaan yang bersifat khas dan pribadi. Sedangkan yang dimaksud dengan pemegang hak cipta berdasarkan pengaturan lebih lanjut mengenai konsep pencipta diatur dalam Pasal 31 - 37 UU Hak Cipta. Dijabarkan lebih lanjut dalam Pasal 31 UU Hak Cipta bahwa yang dianggap pencipta adalah

a) Disebut dalam ciptaan;

b) Dinyatakan sebagai pencipta pada suatu ciptaan;

c) Disebutkan dalam surat pencatatan ciptaan, dan/atau;

d) Tercantum dalam daftar umum ciptaan sebagai pencipta.

Pasal 1 angka 4 UU Hak Cipta yang dimaksud dengan pemegang hak cipta adalah pencipta sebagai pemilik hak cipta, pihak yang menerima hak tersebut secara sah dari pencipta, atau pihak lain yang menerima lebih lanjut hak dari pihak yang menerima hak tersebut secara sah.

Pasal 31 - 37 UU Hak Cipta tersebut menggunakan standar ganda dalam menentukan siapa yang dapat disebut sebagai pencipta yaitu formal deklaratoir dan informal deklaratoir. Pasal 31 UU Hak Cipta menegaskan bahwa daoat disebut sebagai pencipta apabila secara sah disebutkan dalam surat pencatatan ciptaan atau tercantum dalam daftar uu ciptaan. Sedangkan Pasal 32 - 37 UU Hak Cipta menjabarkan informal deklaratoir dimana dapat disebut pencipta apabila memenuhi beberapa kondisi yang disebut dalam beberapa pasal tersebut.

\section{4) Penerbitan ciptaan, penggandaan ciptaan dalam segala bentuknya, pendistribusian ciptaan atau salinannya, dan pengumuman ciptaan}

Penerbitan ciptaan, penggandaan ciptaan dalam segala bentuknya, pendistribusian ciptaan atau salinannya, dan pengumuman ciptaan merupakan hak ekonomi dimana pencipta atau pemegang hak cipta memiliki hak eksklusif untuk mendapatkan manfaat ekonomi atas ciptaan (vide Pasal 8 UU Hak Cipta). Apabila ada pihak yang ingin memanfaatkan hak - hak tersebut harus seizin dari pemegang hak cipta.

\section{5) Penggunaan secara komersial}

Dijabarkan dalam Pasal 1 angka 24 UU Hak Cipta yang dimaksud dengan penggunaan secara komersial adalah 
pemanfaatan ciptaan dan/atau produk Hak Terkait dengan tujuan untuk memperoleh keuntungan ekonomi dari berbagai sumber atau berbayar. Tujuan perbuatannya harus untuk tujuan komersial yaitu mencari keuntungan untuk diri sendiri dengan tanpa memberikan sebagian hasilnya kepada pemegang hak cipta atau pencipta sebagai royalti.

\section{6) Dilakukan dalam bentuk pembajakan}

Dijabarkan dalam Pasal 1 angka 23 UU Hak Cipta yang dimaksud pembajakan adalah penggandaan ciptaan dan/atau produk hak terkait secara tidak sah

dan pendistribusian barang hasil penggandaan dimaksud secara luas untuk memperoleh keuntungan ekonomi. Perbuatan pelaku tindak pidana pembajakan harus dapat dibuktikan bahwa telah dilakukan penggandaan ciptaan dan/atau produk hak terkait secara tidak sah. Ketidaksahan tersebut dapat dilihat apakah pelaku merupakan pencipta atau pemegang hak cipta atau yang mendapatkan peralihan hak cipta tersebut.

UU Hak Cipta mengatur semua tindak pidana hak cipta adalah delik aduan dengan beberapa pertimbangan yaitu
a) Yang dapat menentukan dan memperbandingkan barang hasil pelanggaran hak cipta dengan pemilik

aslinya, hanya pencipta atau pemegang hak cipta, yang dapat lebih meyakini mana merupakan merupakan ciptaan asli dan tiruan dari ciptaan asli.

b) Dalam proses penegakan hukum oleh aparat penegak hukum tidak mungkin langsung mengetahui apakah suatu pihak telah mendapat izin untuk mengumumkan atau memperbanyak suatu ciptaan.

c) Realita dimasyarakat lebih menghendaki adanya penyelesaian secara keperdataan untuk meminta ganti rugi dibandingkan pemidanaan terhadap pelaku tindak pidana hak cipta.

\section{c) Sanksi Pidana Tindak Pidana Pembajakan}

Peraturan-peraturan hukum pidana umum di Indonesia terwujud dalam Kitab Undang-Undang Hukum Pidana (KUHP), sedangkan peraturan-peraturan hukum pidana khusus seperti UU Hak Cipta mengatur secara khusus dan tersendiri tentang delik-delik tertentu lebih mendalam daripada pengaturan dalam KUHP yang bersifat umum. Ketentuan pidana dalam UU Hak Cipta harus dianggap lex specialis, karena secara khusus mengatur hak cipta (lex specialis derogat lex generalis). Namun demikian, kecenderungannya ialah hanya memfokuskan perhatian terhadap Undang- 
Undang Hak Cipta, tanpa menyentuh substansi ketentuan pidana dalam KUHP. Hal ini dapat dimengerti, dengan membaca dan membandingkan sanksi pidana yang diancam oleh, baik KUHP maupun UU Hak Cipta. Dalam UU Hak Cipta, sekalipun diancamkan secara alternatif, jumlah pidana dendanya jauh lebih tinggi dibandingkan dengan denda yang diancamkan dalam KUHP. Berdasarkan Pasal 105 UU Hak Cipta, bahwa hak untuk mengajukan gugatan ganti rugi sebagaimana diatur dalam Pasal 96 ayat (1) UU Hak Cipta, tidak mengurangi hak negara untuk melakukan tuntutan pidana pada setiap pelanggaran hak cipta.

Negara berkewajiban mengusut setiap pelanggaran hak cipta yang terjadi. Hal ini didasarkan pada kerugian yang ditimbulkan oleh tindakan pelanggaran hak cipta, yang tidak saja diderita oleh pemilik atau pemegang hak cipta dan hak terkait, tetapi juga oleh negara, karena kurangnya pendapatan negara yang seharusnya bisa didapat dari pemegang hak cipta atau hak terkait. Selain itu negara harus melindungi kepentingan pemilik hak, agar haknya jangan sampai dilanggar oleh pihak-pihak yang tidak bertanggung jawab.

Perlindungan melalui ketentuanketentuan pidana, seperti yang diatur dalam Pasal 382 bis KUHP yang lazim dikenal sebagai persaingan curang (oneerlijke concurrentie). Persaingan curang merupakan perbuatan untuk menyesatkan khalayak umum atau seseorang tertentu dengan maksud untuk mendapatkan, melangsungkan, atau memperluas debit perdagangan atau perusahaan kepunyaan sendiri atau orang lain.

Dengan UU Hak Cipta, pengaturan mengenai ketentuan pidana telah berubah secara mendasar. Pada UU Hak Cipta Tahun 2002 ada ketentuan penjara minimum. Sedangkan UU Hak Cipta Tahun 2014 sanksi pidana diatur dalam bentuk stelsel maksimal dimana UU Hak Cipta mengatur pidana penjara maksimal 10 tahun dan denda maksimal paling banyak 4 Milyar. Kenaikan hukuman denda yang sangat besar itu dimaksudkan agar ada efek jera bagi mereka yang melakukan pelanggaran, karena denda Rp. 100.000.000,00 (seratus juta rupiah) dianggap masih ringan oleh para pelanggar, karena keuntungan (profit gain) yang diperoleh jauh lebih besar dibandingkan denda yang dijatuhkan.

\section{Penegakan Hukum Atas Tindak Pidana Pembajakan CD/DVD}

Penegakan hukum merupakan rangkaian proses untuk menjabarkan nilai, ide, cita yang cukup abstrak yang menjadi tujuan hukum. Tujuan hukum atau cita hukum memuat nilai-nilai moral seperti keadilan dan kebenaran. Nilai - nilai 
tersebut harus mampu diwujudkan dalam realitas nyata. Eksistensi hukum diakui apabila nilai - nilai moral yang terkandung dalam hukum tersebut mampu diimplementasikan atau tidak.

Secara konseptual, inti dan arti penegakan hukum menurut Soerjono Soekanto terletak pada kegiatan menyerasikan hubungan nilai - nilai yang terjabarkan dalam kaidah - kaidah yang mantap dan mengejawantah dan sikap tindak sebagai serangkaian penjabaran nilai tahap akhir untuk menciptakan, memelihara, dan mempertahankan kedamaian pergaulan hidup (Soekanto, $1985,: 5)$

Politik hukum pidana sebagai salah satu usaha penanggulangan kejahatan, mengejawantah dalam bentuk penegakan hukum pidana yang rasional. Ada tiga tahap dalam penegakan hukum pidana yaitu (Jaya, $2010: 8$ )

a) Tahap formulasi, yaitu tahap penegakan hukum pidana inabstracto oleh badan pembuat undang-undang. Dalam tahap ini pembuat undangundang melakukan kegiatan memilih nilai-nilai yang sesuai dengan keadaan dan situasi masa kini yang akan datang. Kemudian merumuskannya dalam bentuk peraturan perundangundangan pidana untuk mencapai hasil perundang-undangan pidana yang paling baik dalam arti memenuhi syarat keadilan dan daya guna. Tahap ini dapat pula disebut tahap kebijakan legislatif.

b) Tahap aplikasi, yaitu tahap penegakan hukum pidana (tahap penerapan hukum pidana) oleh aparataparat penegak hukum mulai dari kepolisian sampai Pengadilan. Dalam tahap ini aparat penegak hukum bertugas menegakan serta menerapkan peraturan perundang-undangan pidana yang telah dibuat oleh pembuat undang-undang. Dalam melaksanakan tugas ini, aparat penegak hukum harus berpegang teguh pada nilai-nilai keadilan dan daya guna. Tahap kedua ini dapat pula disebut sebagai tahap kebijakan yudikatif.

c) Tahap eksekusi, yaitu tahap penegakan (pelaksanaan) hukum pidana secara konkret oleh aparataparat pelaksana pidana. Dalam tahap ini aparat-aparat pelaksana pidana bertugas menegakan peraturan perundang-undangan pidana yang telah dibuat oleh pembuat undangundang melalui penerapan pidana yang telah ditetapkan dalam putusan pengadilan. Dalam melaksanakan pemidanaan yang telah ditetapkan dalam putusan pengadilan, aparataparat pelaksana pidana ini dalam menjalankan tugasnya harus 
berpedoman kepada peraturan perundang-undangan pidana yang dibuat oleh pembuat undang-undang dan nilai-nilai keadilan serta daya guna.

Ketiga tahap penegakan hukum pidana tersebut, dilihat sebagai suatu usaha atau proses yang rasional yang sengaja direncanakan untuk mencapai tujuan tertentu, jelas harus merupakan suatu jalinan mata rantai aktivitas yang tidak terputus yang bersumber dari nilai-nilai dan bermuara pada pidana dan pemidanaan. Penegakan hukum merupakan upaya menegakkan norma hukum terhadap pelanggaran yang dilakukan. Penegakan hukum dijalankan untuk menjaga, mengawal, dan mengantar hukum agar tetap tegak, searah dengan tujuan hukum dan tidak dilanggar oleh siapapun. Kegiatan penegakan hukum merupakan kegiatan penerapan hukum terhadap pelanggaran norma hukum.

Di dalam artikel ini akan dibahas mengenai pelaksanaan penegakan hukum yang merupakan tahap aplikasi. Dalam tahap aplikasi ini Aparat Penegak Hukum bertugas menegakkan serta menerapkan peraturan perundang-undangan pidana yang telah dibuat oleh Pembuat UndangUndang. Dalam melaksanakan tugas ini, Aparat Penegak Hukum harus berpegang teguh pada nilai-nilai keadilan dan daya guna.

Joseph Goldstein, membedakan penegakan hukum pidana atas 3 (tiga) macam yaitu (Muladi, $2001: 16$ ):

"Pertama, Total Enforcement, yakni ruang lingkup penegakan hukum pidana sebagaimana yang dirumuskan oleh hukum pidana substantif. Penegakan hukum yang pertama ini tidak mungkin dilakukan sebab para penegak hukum dibatasi secara ketat oleh hukum acara pidana. Disamping itu, hukum pidana substantif itu sendiri memiliki kemungkinan memberikan batasan-batasan Ruang lingkup yang dibatasi ini disebut dengan area of no enforcement. Kedua, Full Enforcement, yaitu Total Enforcement setelah dikurangi area of not enforcement, dimana penegak hukum diharapkan menegakkan hukum secara maksimal, tetapi menurut Goldstein hal inipun sulit untuk dicapai (not a realistic expectation), sebab adanya keterbatasan-keterbatasan dalam bentuk waktu, personal, alat-alat dana dan sebagainya yang dapat menyebabkan dilakukannya diskresi, Ketiga, Actual 


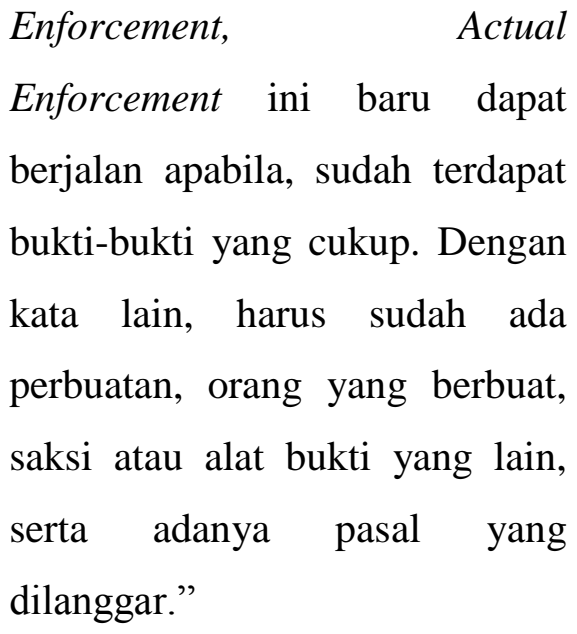

Untuk mensukseskan penegakan hukum tentu saja penegak hukum tidak bisa berdiri sendiri hanya berlandaskan pada peraturan perundang-undangan saja melainkan juga harus melihat kondisi dalam masyarakat. Sehingga dapat diketahui bahwa proses penegakan hukum itu sendiri melibatkan sistem hukum yang sangat terkait. Lawrence M. Friedman membedakan unsur sistem hukum ke dalam tiga macam, yaitu: "Struktur Hukum (Legal structure), Substansi Hukum (Legal substance), Kultur Hukum (Legal culture)". Menurut Friedman kebanyakan negara-negara berkembang dalam upaya penegakan hukum hanya menyangkut struktur dan substansinya saja, sedangkan masalah kultur hukum kurang mendapatkan perhatian yang seksama.

Penegakan hukum pidana, secara fungsional akan melibatkan minimal 3 (tiga) faktor yang saling terkait, yaitu faktor perundang-undangan; faktor aparat/penegak hukum; dan faktor kesadaran hukum. Faktor perundangundangan-dalam hal ini perundangundangan pidana, meliputi hukum pidana materiil (hukum pidana substantif), hukum pidana formil (hukum acara pidana) maupun hukum pelaksanaan pidana. Berkaitan dengan faktor perundangundangan pidana ini, Bagir Manan mengatakan, bahwa dua aspek penting dalam keberhasilan penegakan hukum pidana tersebut, adalah isi/hasil penegakan hukum (substantif justice) dan tata cara penegakan hukum (procedural justice).

Untuk faktor perundang-undangan inipun terkait dengan tahapan-tahapan kebijakan formulatif (legislatif). Kebijakan aplikatif (yudikatif) dan kebijakan administratif (eksekusi). Dapat dikatakan, bahwa pada tahap kebijakan formulatif merupakan penegakan hukum "in abstracto", yang pada gilirannya akan diwujudkan dalam penegakan hukum "in concreto" (melalui tahap kebijakan aplikasi dan eksekusi).

Dalam proses bekerjanya aparat penegak hukum itu, terdapat 3 elemen penting yang mempengaruhi, yaitu (Prodjodikoro, 2000 : 67) :

a) Institusi penegak hukum beserta berbagai perangkat sarana dan prasarana pendukung dan mekanisme kerja kelembagaannya; 
b) Budaya kerja yang terkait dengan aparatnya, termasuk mengenai kesejahteraan aparatnya, dan

c) Perangkat peraturan yang mendukung baik kinerja kelembagaannya maupun yang mengatur materi hukum yang dijadikan standar kerja, baik Hukum materilnya maupun hukum acaranya. Upaya penegakan Hukum secara sistematik haruslah memperhatikan ketiga aspek itu secara simultan, sehingga proses penegakan hukum dan keadilan itu sendiri secara internal dapat diwujudkan secara nyata.

Namun, selain ketiga faktor diatas, keluhan berkenaan dengan kinerja penegakan hukum di negara kita selama ini, sebenarnya juga memerlukan analisis yang lebih menyeluruh lagi. Upaya penegakan hukum hanya satu elemen saja dari keseluruhan persoalan kita sebagai negara hukum yang mencita-citakan upaya menegakan dan mewujudkan keadilan sosial bagi seluruh rakyat Indonesia.

Hukum tidak mungkin akan ditegakkan jika hukum itu sendiri atau belum mencerminkan perasaan atau nilainilai keadilan yang hidup dalam masyarakatnya. Hukum tidak mungkin menjamin keadilan jika materinya sebagian besar merupakan warisan masa lalu yang tidak sesuai dengan tuntutan zaman, Artinya, persoalan yang kita hadapi bukan saja berkenaan dengan upaya penegakan hukum tetapi juga pembaharuan hukum atau pembuatan hukum baru. Karena itu, ada beberapa fungsi penting yang memerlukan perhatian yang seksama, yaitu:

a) Pembuatan hukum (the legislation of law atau Law and rule making),

b) Sosialisasi, penyebarluasan dan bahkan pembudayaan hukum (sosialization and promulgation of law) dan

c) Penegakan hukum (the enforcement of law).

Dalam melakukan penegakan hukum, kepastian hukum, keadilan dan kemanfaatan bagi masyarakat merupakan hal yang harus diperhatikan oleh penegak hukum. Jika hukum ditegakkan terhadap pelanggar hukum misalnya memberikan hukuman bagi pelanggar hak cipta sesuai dengan ketentuan hukum yang berlaku maka diharapkan peredaran kaset/VCD bajakan tidak terjadi lagi dalam masyarakat. Hal ini akan memberikan kepada setiap pencipta motivasi untuk selalu menghasilkan karya-karya yang berkualitas dan bermutu sehingga memberikan manfaat bagi masyarakat banyak. Namun dalam melaksanakan penegakan hukum, hal ini tidak selalu mudah dilakukan karena banyak faktorfaktor yang mempengaruhi. Faktor-faktor 
tersebut adalah sebagai berikut (Soekanto, $1983: 8)$ :

a) Faktor hukumnya sendiri, yang didalamnya dibatasi pada UndangUndang saja;

b) Faktor penegak hukum, yakni pihakpihak yang membentuk maupun yang menerapkan hukum;

c) Faktor sarana atau fasilitas yang mendukung penegakan hukum;

d) Faktor masyarakat, yakni lingkungan dimana hukum tersebut berlaku atau diterapkan;

e) Faktor kebudayaan, yakni sebagai hasil karya, cipta dan rasa yang didasarkan pada karsa manusia di dalam pergaulan hidup.

Kelima faktor tersebut saling berkaitan dengan erat, karena merupakan esensi dari penegakan hukum, juga merupakan tolak ukur dari pada efektivitas penegakan hukum.

\section{Simpulan}

Dalam Islam, tidak dikenal istilah pembajakan. Akan tetapi, apabila ditinjau dari hakekatnya pembajakan merupakan pencurian hak milik orang lain yang seharusnya dijaga dan dihormati agar tidak menimbulkan kerugian bagi pemilik hak cipta tersebut. Larangan melakukan pembajakan didasarkan pada Q.S. Al Baqarah Ayat 188 dan Q.S. Al - Maidah ayat 38. Pembajakan hak cipta atau yang dalam bahasa Inggris disebut piracy merupakan penggandaan secara tidak sah atau ilegal dan selanjutnya di distribusikan terhadap suatu produk atau barang yang terdaftar sebagai hak cipta, paten, atau merk. UU Hak Cipta mengatur sanksi pidana dalam bentuk stelsel maksimal dimana pidana penjara maksimal 10 tahun dan denda maksimal paling banyak 4 Milyar. Kenaikan hukuman denda yang sangat besar itu dimaksudkan agar ada efek jera bagi mereka yang melakukan pelanggaran, karena denda Rp. 100.000.000,00 (seratus juta rupiah) dianggap masih ringan oleh para pelanggar, karena keuntungan (profit gain) yang diperoleh jauh lebih besar dibandingkan denda yang dijatuhkan. Penegakan hukum terhadap pelanggaran di bidang hak cipta oleh aparat penegak hukum dapat dilakukan dengan cara preventif dan represif. Untuk penegakan hukum preventif dilakukan melalui sarana sosialisasi bentuk - bentuk tindak pidana hak cipta. Sedangkan penegakan hukum secara represif dilakukan melalui sistem peradilan pidana.

\section{Daftar Pustaka}

\section{Buku}

Ali, Achmad, 1998, Menjelajahi Kajian Empiris Terhadap Hukum, Jakarta : Yarsif Watampone, 
Arief, Barda Nawawi, 1998, Beberapa Aspek Kebijakan Pengakan Dan Pembangunan Hukum Pidana, Bandung : Citra Aditya Bakti,.

Garner, Bryan A., 2004, Black's Law Dictionary, USA : Thomson Business.

Hamzah, Andi, 1994, Asas-Asas Hukum Pidana, Jakarta : Rineka Cipta.

Hanitijo, Soemitro Ronny, Metode Penelitian Hukum dan Yurimetri, Jakarta : Ghalia Indonesia, 1988.

Jaya, Nyoman Serikat Putra, 2010, Sistem Peradilan Pidana (Criminal Justice System), Semarang: Badan Penerbit UNDIP.

Muladi, Kapita Selekta Sistem Peradilan Pidana, Semarang : Badan Penerbit Universitas Diponegoro, 1995.

Soekanto, Soerjono, 1983, Faktor-Faktor yang Mempengaruhi Penegakan Hukum, Jakarta : Raja Grafindo Persada.

Prodjodikoro, Wrjono, 1980, TindakTindak Pidana Tertentu di Indonesia, Jakarta : Eresco.

, 2000, Perbuatan Melanggar Hukum Dipandang dari Sudut Hukum Perdata, Bandung : Mandar Maju.

Wiyanto, Wihadi, 2002, Lampiran Makalah Penerapan UndangUndang No. 19 Tahun 2002 Tentang Hak Cipta Dalam Rangka Memerangi Pembajaka.

\section{Artikel Jurnal}

Wicaksono, Aditya Pandu dan Dekar Urumsah, 2017, "Perilaku Pembajakan Produk Digital :
Cerita Dari Mahasiswa Yogyakarta", Jurnal Aplikasi Bisnis, Volume 17 Nomor 1 Bulan Juli.

Mujahid Quraisy, 2011, "Hak Kekayaan Intelektual (HaKI) dalam Perspektif Hukum Islam, Junal Muqtasid, Volume 2, Nomor 1.

\section{Makalah}

Suharto, Etty S., 2002, Modul : Pelanggaran Hak Cipta Pada Media Internet Pelatihan Hak Kekayaan Intelektual. Klinik HKI Fakultas Hukum Undip. Semarang 23 September.

\section{Internet}

https://www.kompasiana.com/rokyul57/58 50dbf7927a610a38e229b5/hakcipta-dalam-pandangan-islam\#.

https://www.kompasiana.com/iis80/5913d e58717a61eb07a38938/hak-ciptadalam-perspektif-islam. 